\title{
Ross Chambers, Rimbaud and the forain (on "Au Cabaret-Vert, cinq heures du soir")
}

\section{Damiano Sinfonico}

\section{Q OpenEdition}

1 Journals

\section{Edizione digitale}

URL: http://journals.openedition.org/studifrancesi/6372

DOI: $10.4000 /$ studifrancesi.6372

ISSN: 2421-5856

\section{Editore}

Rosenberg \& Sellier

\section{Edizione cartacea}

Data di pubblicazione: 1 novembre 2010

Paginazione: 574

ISSN: 0039-2944

\section{Notizia bibliografica digitale}

Damiano Sinfonico, «Ross Chambers, Rimbaud and the forain (on "Au Cabaret-Vert, cinq heures du soir")》, Studi Francesi [Online], 162 (LIV | III) | 2010, online dal 30 novembre 2015, consultato il 10 janvier 2021. URL: http://journals.openedition.org/studifrancesi/6372 ; DOI: https://doi.org/10.4000/studifrancesi. 6372

Questo documento è stato generato automaticamente il 10 janvier 2021.

\section{(c) 9 (i) $\Theta$}

Studi Francesi è distribuita con Licenza Creative Commons Attribuzione - Non commerciale - Non opere derivate 4.0 Internazionale. 


\title{
Ross Chambers, Rimbaud and the forain (on "Au Cabaret-Vert, cinq heures du soir")
}

\author{
Damiano Sinfonico
}

\section{NOTIZIA}

ROSS CHAMBERS, Rimbaud and the forain (on "Au Cabaret-Vert, cinq heures du soir"), in «Australian Journal of French Studies», volume XLIV, 1, 2007, pp. 3-12.

1 L'A. conduce un discorso ad anelli, incentrandolo sull'analisi magistrale del sonetto $\mathrm{Au}$ Cabaret-Vert, cinq heures du soir (ottobre 1870): il testo, considerato un'anticipazione delle lettres du voyant (maggio 1871) perché tende verso l'illuminazione finale, è percepito come l'incrocio esemplare tra un tipo di poesia descrittivo e un tipo figurativo: il realismo si carica di sovrasenso, l'adesione al particolare oggettivo diventa uno stadio nel percorso che porta all'illuminazione. Questo bifrontismo caratterizza per l'A. la poesia del forain, il «seller of rethorique» che tra un'esigenza mimetica e una figurativa rende esteticamente più appetibile il quotidiano: nello scarto rispetto all'ordinario e al familiare, questa sovrapposizione estetica aderisce al nuovo status di saltimbanco del poeta, che sfrutta le risorse del linguaggio per rivestire il quotidiano e legittimare un'utilità della poesia. 